\title{
An economic analysis of poorly sited septic systems
}

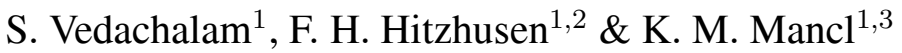 \\ ${ }^{1}$ Environmental Science Graduate Program, \\ The Ohio State University, USA \\ ${ }^{2}$ Agricultural, Environmental, and Development Economics, \\ The Ohio State University, USA \\ ${ }^{3}$ Food, Agricultural and Biological Engineering, \\ The Ohio State University, USA
}

\begin{abstract}
Soil-based septic systems serve about one in every four households in the United States. Proper design and quality of soil play an important role in the functioning of such systems. Shallow soils in the state of Ohio do not support traditional leach field systems that require a depth of 3 to 4 feet of soil for effective treatment of domestic wastewater. Installation of such systems in areas with shallow or saturated soils leads to incomplete treatment of organic and bacterial pollutants. Untreated or partially treated wastewater not only affects the immediate residents, but also contaminates the groundwater aquifer and the local watershed. Drinking contaminated water could lead to illness and a subsequent decrease in the quality of life, and a loss of property valuation. This study aims to isolate the effect of poor site selection on the value of the property. The assessed sale price of 549 randomly selected properties in Licking County, Ohio was analyzed and compared across various structural, community and environmental factors. Results indicate that properties sited on soils that are deemed optimal for wastewater treatment are valued, on average, $\$ 15,752$ higher than those sited on sub-optimal soils. The results from this study would not only help the property owners in making better private decisions regarding installation of septic systems, but would also guide policy decisions that affect public health and common waters.

Keywords: septic systems, soil quality, property valuation, hedonic analysis, Ohio.
\end{abstract}




\section{Introduction}

Early settlement in the U.S. occurred along the banks of rivers or near the seashore (e.g., Chicago, New York and Philadelphia), where human and animal waste was discharged directly into the water body. By the 1850s, cesspools or holding tanks located outside the residence were used to contain waste. Because of the need to frequently empty the holding tank, maintenance was quite expensive and over time, most of the contained waste was slowly discharged to a nearby stream. By the 1880 s, cities like Baltimore were facing large-scale public health problems due to the indiscriminate discharge of pollutants [1]. By the end of the century, strict regulations on the use of cesspools limited propagation of the practice, and waste was discharged through open gutters. It was only later in the 20 th century that urban areas were connected to closed sewer pipes and rural areas started using septic systems.

Regulations governing the installation and use of septic systems in Ohio were written in the Ohio Administrative Code in the year 1977 [2]. In spite of the new technologies developed during the last 30 years, the Ohio Administrative Code has not been modified to reflect the availability of superior treatment techniques and the knowledge gained about public health risks from siting septic systems in unsuitable soils. This study aims to identify the relationship between the quality of soil used to site the septic system and the market value of a residential property. The results from the study will not only enable residents make better private decisions regarding installation of septic systems, but also guide policy decisions affecting wastewater management and public health in rural areas.

\section{Septic systems}

Soil-based septic systems serve between 20-25\% of the households in the United States [3, 4]. Soil standards developed at The Ohio State University suggest a minimum depth of $4 \mathrm{ft}$ of deep, permeable soil to obtain complete removal of pollutants. In a well-functioning septic system, $4 \mathrm{ft}$ of soil can remove the following pollutants: suspended solids, organic matter, bacteria, ammonia and viruses [5]. However, only $6.4 \%$ of the soils in Ohio are deeper than $4 \mathrm{ft}$ and suited for traditional leach field systems. Advanced systems such as mound, media filter, aerobic lagoons, etc. augment the treatment capabilities of natural soils, such that only $2 \mathrm{ft}$ of soil or less is needed to achieve complete removal of the pollutants. However, high cost of installation and maintenance of these advanced systems, along with lack of strict standards in Ohio counties [2] have made leach field systems the default choice in an overwhelming majority of Ohio households. The Ohio Department of Health notes that Ohio has the oldest sewage rules in the United States. Several alternative technologies have been developed and improved in the last 30 years, starting with the mound system developed by Converse [6] at the University of Wisconsin in 1978 for installation in areas with shallow soil depths. Also called the Wisconsin mound for its place of origin, this technique used a layer of sand placed above natural soil to augment its treatment capacity. 
In 2007, The Ohio Department of Health was directed by the Ohio legislature to prepare a comprehensive analysis on the types of alternative waste treatment systems, and their costs and economic factors. Information on permits for treatment systems installed between July 1, 2007 and May 1, 2008 revealed that new household systems accounted for $65 \%$ of all systems installed, while replacement and alterations were $21 \%$ and $13 \%$ of the total, respectively. Additionally, $67 \%$ of all systems installed were septic systems with traditional leach lines, $14 \%$ were mound systems, 3\% were drip irrigation systems, 6\% were NPDES-approved discharging systems (replacements of existing discharging systems), while the remaining $6 \%$ were other systems or systems with no information. The average estimated cost of installing these systems are as follows: $\$ 7,250$ for septic systems with leach fields, $\$ 14,150$ for mound systems and $\$ 19,750$ for drip irrigation systems [7].

\subsection{Failure and its impact}

Approximately $25 \%$ of Ohio's households are served by some type of sewage system located on the property, with an estimated one million systems in use today. Seasonal saturation in the soils and the presence of bedrock represent conditions that do not allow for the treatment of wastewater necessary to keep communities safe [7]. The number of replacement and alteration systems constitutes $34 \%$ of the total installed systems during the period July 1, 2007 through May 1, 2008. This number matches the statewide failure rate of septic systems reported in earlier studies: $27 \%$ [8, 9], 13-20\% [10], and 20-25\% [11]. The failure of septic systems has been attributed to various reasons, primary among them being inadequate soil quality, under-design, age of the system $[12,13]$, and failure to remove excess sludge from the septic tank [13].

Installation of leach field systems in shallow and saturated soils leads to incomplete treatment and discharge of pollutants. The resulting effects could be contamination of ground and surface water with microorganisms, surfacing effluents and odors. Untreated waste discharged to shallow soils travels vertically through the unsaturated zone and contaminates ground water. Once in ground water, bacteria and viruses are transported to long distances in a short period of time [14]. Partially treated wastewater discharged into saturated soils can lead to run-off of nutrients such as phosphorus into nearby lakes and streams. Consumption of contaminated ground water; or contact with contaminated soil or run-off water presents potential health risks for humans, pets and wildlife [15].

Various studies have shown contamination of ground water from malfunctioning septic systems. Arnade [16] tested drinking water for fecal coliforms, nitrates and phosphates from residential wells in Palm Bay, Florida and found that samples collected during the wet season contained significantly higher concentrations of microbial and inorganic pollutants compared with samples collected in the dry season. A statistically strong correlation was also established between decreasing distance between wells and septic tanks and increasing pollutant concentration in the drinking water. DeBorde et al. [17] identified coliphage at high concentrations 
in both septic tank effluents and the underlying ground water in a test conducted at a high school located in western Montana. Yates [18] reviewed several studies that identified correlation between density of septic systems and contamination of ground water, a result that was corroborated by Borchardt et al. [19]. Yates [18] reviewed several studies that document outbreaks of Hepatitis A, typhoid and gastroenteritis traced to contamination of groundwater from septic tank effluent. Septic systems density was also associated with endemic diarrheal illness in children [19]. The massive gastrointestinal outbreak in South Bass Island, Ohio in 2004 was traced to the contamination of groundwater through septic tanks and other wastewater treatment facilities [20].

\subsection{Private costs}

Large-scale system failures may result in enforcement action from the Environmental Protection Agency. Records from Ohio EPA show that during the period 1986-2007, over 240 communities were under enforcement or had been identified as having significant impacts from failing systems [7]. However, the costs of failing systems are difficult to measure, especially at the individual level. Other than the negative health effects and the resulting cost of illness leading to a decrease in the quality of life, an individual may also encounter higher maintenance and repair costs in case of poorly designed systems, and a loss of property valuation. This study aims to isolate the effect of poor site selection and design on the value of the property. The authors are aware of no similar study undertaken so far. Hence, as much as these results cannot be benchmarked against previous studies, this study opens up new ways of improving the quality of wastewater treatment in rural communities.

\section{Methods}

This study was conducted in Licking County, Ohio (see Figure 1). In 2007, the Licking County Health Department conducted a survey of households using onsite treatment systems and collected key information. The LCHD randomly selected 800 households out of the approximately 15,000 households using onsite systems in the county. The survey contained information such as the parcel code of the property lot, the type of soil, the presence of curtain drains, GPS readings of the onsite systems, and visual observations of the treatment system and its surroundings. Of the 800 households, 616 households used soil-based septic systems, while 184 households used aerator treatment systems. Since the aerator systems utilize mechanical equipments, their performance is not affected by the quality of soil. Hence these households were not included in this study. Households that did not contain information on the type of soil or could not be located on the county auditor's records were removed from the study, and so were households categorized as agricultural properties by the county auditor. The remaining 549 residential properties were analyzed further as part of the study. Although, the effective sample size reduced from 800 to 549 households, the 


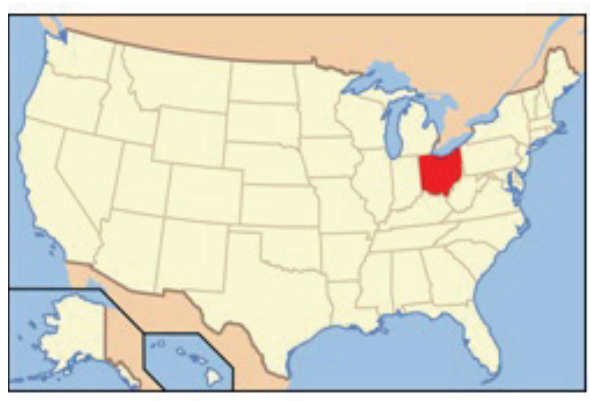

(a)

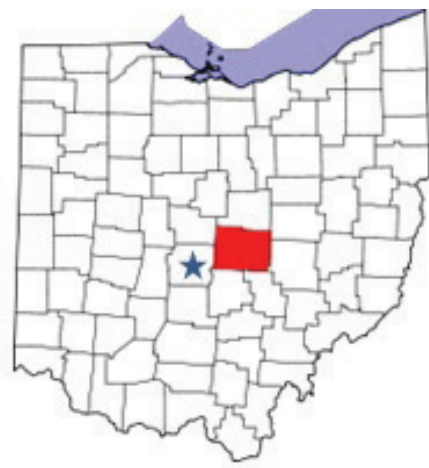

(b)

Figure 1: (a) Map of the U.S. with Ohio highlighted (source: Wikimedia Commons), and (b) Location of Licking County within Ohio.

sample is statistically representative of all the households in the county using septic systems with $2 \%$ sampling error at the $95 \%$ confidence level.

Mancl and Slater [21] categorized the soils found in Ohio in four categories, depending on their ability to remove pollutants such as suspended solids, ammonia, organic matter, bacteria and viruses from domestic wastewater. Based on the depth of these soils between the bottom of a sewage leaching trench and a limiting condition, they are:

1. soils up to $4 \mathrm{ft}$ deep, suited for leach fields,

2. soils up to $2 \mathrm{ft}$ deep, suited for mound systems,

3. soils up to $1 \mathrm{ft}$ deep, suited for irrigation of treated wastewater, and

4. soils less than $1 \mathrm{ft}$ deep, not suited for onsite systems.

The following table shows the distribution of these soils across Ohio, in Licking County and in the sample selected for the study.

As seen in Table 1, Licking County has higher percentages of soils suited

Table 1: Distribution of soils based on their ability to treat wastewater.

\begin{tabular}{|c|l|l|l|l|}
\hline \multirow{2}{*}{ Region } & \multicolumn{4}{|c|}{ Percentage of Soils Suitable } \\
\cline { 2 - 5 } & $\begin{array}{l}\text { Leach } \\
\text { fields }\end{array}$ & $\begin{array}{l}\text { Mound } \\
\text { systems }\end{array}$ & $\begin{array}{l}\text { Onsite treatment } \\
\text { with irrigation }\end{array}$ & $\begin{array}{l}\text { Not suited for } \\
\text { onsite systems }\end{array}$ \\
\hline Ohio & 6.4 & 25.4 & 49.1 & 19.1 \\
\hline Licking County & 16.3 & 38.2 & 33.8 & 11.7 \\
\hline Sample & 29.3 & 48.6 & 17.3 & 4.7 \\
\hline
\end{tabular}


for leach fields and mound systems than the average soils in Ohio. Assuming the survey sample to be representative of Licking County, a significantly higher proportion of residents purchased or built houses in soils suited for either leach fields or mound systems as compared to the average percentage of soils found in the county.

Apart from the soil type, the survey collected information on whether the septic system also included a curtain drain; an artificially drained septic system that lowers the water table and carries the waste stream away from the property. The parcel code of the properties were entered in the online property management database of Licking County and specific information on each property such as size of the lot, age of the property, number of bedrooms and baths, etc. were obtained, along with the assessed sale price of each property on January 1, 2008. Licking County has 26 townships, of which 20 are zoned. The zoning status of the township was included in the model, as was the quality of the school districts in the county. Licking County has 11 school districts, including one that is primarily based in the neighboring Knox County. The Ohio Department of Education issues an annual report card, where school districts across the state are measured on various parameters including a 'Performance Index Score', which is the weighted average of the school districts' assessment results across all tested grades and all subjects. The 'Performance Index Score', being a composite score, was thought to be a good predictor of the quality of the school district and was used in the model. Additional information such as distance to nearby urban centers like the state capital Columbus (Franklin County) and Newark (county seat and the largest city in Licking County), and recreational sites such as Buckeye Lake was calculated using the ArcGIS software and added to the model to account for property valuations influenced by proximity to these locations.

\section{Hedonic price method}

Environmental economists have used non-market valuation techniques to identify the benefits of environmental attributes that do not have a market value of their own, such as air and water quality [22]. One of the methods to value environmental attributes is hedonic pricing method. Hedonic pricing method has been extensively used to measure increases in property values due to changes in river water quality in a neighborhood [23]. Hedonic pricing method measures the price differentials that arise due to quality differences across similar goods. Hedonic pricing uses the different characteristics of a traded good, such as real estate, to estimate the value of a non-traded good, such as water or soil quality [24]. By correcting and/or controlling for other factors that would influence the value of a particular property, it is possible to isolate the hidden value of the amenity, in this case, the value of a well-sited septic system. The price of a residential property $\mathrm{P}$ is defined by a hedonic function:

$$
P_{i}=f\left(S_{i}, C_{i}, Q_{i}\right)
$$


where $S_{i}$ represents the structural characteristics, $C_{i}$ represents the community characteristics and $Q_{i}$ represents the environmental characteristics. Structural characteristics of a property include physical attributes such as size of the plot, age, number of rooms, etc. Other things being equal, it is expected that an additional bath or bedroom represents an extra amenity. Community characteristics include distance to the nearby urban and recreational centers, zoning status of the township and quality of the school district. Zoning protects neighborhood residents from externalities arising out of unfavorable land-use. By preventing undesirable uses, zoning is beneficial to the residents and therefore, is expected to increase the value of the property. School district performance is expected to be positively correlated with price. Environmental characteristics include presence of curtain drains and the type of soil. In a study conducted on the Muskingum River corridor, Hitzhusen et al. [25] found that presence of septic tank significantly affected the price of a property, and its contribution was $\$ 119$ (in 1999 dollars). The hedonic price function for the model is represented as:

$$
P_{j}=\beta_{0}+\Sigma \beta_{s i} S_{i j}+\Sigma \beta_{c i} C_{i j}+\Sigma \beta_{q i} Q_{i j}
$$

where $P_{j}$ is the assessed price of the $j$ th property, $S_{i}$ is the vector of variables describing structural characteristics of the property, $C_{i}$ is the vector of community variables and $Q_{i}$ is the vector of environmental variables.

\section{Results}

In the initial version of the model, the variable 'soil type' was defined as a categorical variable, where each type of soil was listed as a separate category. Using this method, three of the categories entered the model, while the fourth category served as the reference. The reference variable was rotated amongst the four categories, until all possible variations of the model were run. None of the variations yielded significant results for the soil categories, except for one model where the 'onsite treatment with irrigation' soil was the reference variable and 'leach field' and 'mound systems' soils were statistically significant at the $1 \%$ level. Both the variables displayed a positive sign, indicating that properties built on soils suited for leach fields and mound systems were valued more than those built on soils suited for onsite treatment with irrigation, all else being equal. However, soils 'unsuited for onsite systems' was not a significant variable. Although the initial version did not produce results clearly proving or disproving the initial hypothesis, it established that a significant difference in the property prices existed between those that were built on soils suited for leach fields and mound systems versus soils suited for onsite systems with irrigation.

This result was used to run another version of the model where the variable 'soil type' was defined as a binary instead of a categorical variable. Soils suited for leach fields and mound systems were combined and listed as 'optimal' soils. Soils suited for treatment with irrigation and those unsuited for any onsite system were combined and listed as 'sub-optimal' soils. This model yielded significant results 
Table 2: Hedonic price grading estimates.

\begin{tabular}{|c|c|c|c|c|c|c|}
\hline Variable & Min & $\operatorname{Max}$ & Average & $\beta$ & $t$-value & $p$-value \\
\hline Plot Size & 0.431 & 29.89 & 3.76 & .106 & 5.475 & .000 \\
\hline Living Area & 720 & 5935 & 2045.13 & .539 & 13.121 & .000 \\
\hline Full Baths & 1 & 5 & 1.92 & .074 & 3.878 & .000 \\
\hline Rooms & 2 & 11 & 6.63 & .017 & 1.744 & .082 \\
\hline $\begin{array}{l}\text { Fireplace } \\
\text { Openings }\end{array}$ & 0 & 6 & 0.79 & .078 & 5.014 & .000 \\
\hline Age & 3 & 163 & 29.29 & -.223 & -11.544 & .000 \\
\hline $\begin{array}{l}\text { Distance to } \\
\text { Columbus }\end{array}$ & 10.84 & 42.87 & 25.59 & -.009 & -2.784 & .006 \\
\hline $\begin{array}{l}\text { Distance to } \\
\text { Newark }\end{array}$ & 3.15 & 23.29 & 8.98 & -.003 & -.502 & .616 \\
\hline $\begin{array}{l}\text { Distance to } \\
\text { Buckeye Lake }\end{array}$ & 1.8 & 27.61 & 12.43 & .000 & .023 & .982 \\
\hline Zoning & 0 & 1 & 0.84 & .032 & .759 & .448 \\
\hline $\begin{array}{l}\text { School District } \\
\text { Score }\end{array}$ & 92.5 & 104.7 & 97.38 & .018 & 4.99 & .000 \\
\hline Soil Type & 0 & 1 & 0.78 & .088 & 2.873 & .004 \\
\hline Curtain Drain & 0 & 1 & 0.29 & .024 & .917 & .360 \\
\hline
\end{tabular}

Note: Dependent variable $=$ natural logarithm of the assessed market value.

and will be used to draw conclusions from this study. The model explains $80.1 \%$ (adjusted $R^{2}$ ) of the variation in property values in the sample with the independent variables included in the model. Eight out of the 13 estimated coefficients are significantly different from zero at the $5 \%$ level of significance as illustrated in Table 2 .

At the 5\% level of significance, the following variables are significantly different from zero and have a positive impact on the property valuation: plot size, living area, number of baths and fireplace openings, school district performance index, and type of soil. Number of rooms was significant at the $10 \%$ level. Variables having a negative impact, while being significantly different from zero at the $5 \%$ level of significance are distance to Columbus and age of the property. Variables such as zoning, presence of curtain drain, and distance to Newark and Buckeye Lake were not significant in this model.

From the authors' perspective, the key variables in this model were type of soil, presence of curtain drain and the age of the property. While the classification of soils based on their ability to treat wastewater forms the hypothesis for this 
study, curtain drains are relevant due to their unique role in wastewater treatment. Curtain drains are used in areas with shallow soils to avoid interaction between untreated wastewater and groundwater. Although curtain drains cause a negative externality to the society since the wastewater does not get fully treated, but merely moved across underneath the soil, some homeowners benefit from their use since the wastewater no longer remains on their property. The use of curtain drains has become popular in recent years. Of the 116 properties in the sample built in the last 10 years, $65 \%$ of them installed curtain drains. In the sample, the median age of properties using curtain drains is 11 years (S.D. $=19.32$ years), as compared to 34 years (S.D. $=34.57$ years) for those not using curtain drains. Therefore, it was expected that presence of curtain drains would have a positive impact on the property value. However, the variable was not significant in the model.

Most septic systems are designed to last 30 years, when used at design load (wastewater volume, nutrient loading, etc.) and with regular maintenance. However, most homeowners do not replace or repair septic systems until the systems fail completely. Septic systems may be tested at the time of transfer of property or when the county health department conducts inspections based on complaints from either the homeowner or the community. Additionally, county health departments do not keep records of the age of the septic systems. Therefore, it is difficult to assess the age or the performance of the septic systems based on secondary data. Age of the property (median age $=28$ years, S.D. $=23$ years) is used in this model as a proxy for the age of the septic system. The coefficient for property age is negative and significant. Since age is modeled logarithmically, its coefficient in the model represents a percentage change in the price due to a percent change in age, i.e. there is a $0.223 \%$ decrease in the property's price for every one percent increase in age, other things remaining same. The marginal implicit price of age was calculated as $\$ 1,584.3$, based on the assessed market value of the average house, $\$ 208,092$. Although it is difficult to parse out the contribution of the age of the septic system from the age of property, studies cited earlier in this report can be used to hypothesize that older infrastructure has a negative impact on the price. Another interesting observation from the data is that most of the newer properties are being built on soils not suited for onsite treatment. The median age and standard deviation of properties built on the different category soils is given in Table 3 .

As the prime lands in urban and suburban areas have already been used for public and private construction, newer development is spreading to rural areas with soils suited well for agriculture, but not for siting soil-based septic systems. The marginal implicit price for the type of soil was calculated to be $\$ 15,752$. This means that, on average, properties sited on soils suited for leach fields or mound systems are valued $\$ 15,752$ more than properties sited on soils suited for onsite systems with irrigation or soils unsuited for any onsite systems. This difference is higher than the cost of installing a mound system, but less than the cost of installing a drip irrigation system, using the estimates from the Ohio Department of Health. A recent news report about a proposed sewer project in Licking County estimates that homeowners are likely to pay $\$ 14,400$ to connect to the sewer system. This 
Table 3: Age of the property, categorized by the type of soil.

\begin{tabular}{|l|c|l|}
\hline \multirow{2}{*}{ Soil suitable for } & \multicolumn{2}{|c|}{ Age (years) } \\
\cline { 2 - 3 } & Median & $\begin{array}{l}\text { Standard } \\
\text { deviation }\end{array}$ \\
\hline Leach fields & 31 & 14.6 \\
\hline Mound systems & 27 & 25.2 \\
\hline $\begin{array}{l}\text { Onsite treatment with } \\
\text { irrigation }\end{array}$ & 18 & 28.5 \\
\hline $\begin{array}{l}\text { Not suited for onsite } \\
\text { systems }\end{array}$ & 10.5 & 19.4 \\
\hline
\end{tabular}

analysis shows that homeowners have an incentive to adopt advanced treatment systems, and carry our regular maintenance of septic tanks.

\section{Conclusions}

The prohibitive cost of installing sewer networks in the exurban and rural areas of the country makes soil-based septic systems a suitable option, if installed and maintained properly. However, lack of information to the residents and absence of strict policy guidelines governing this issue seem to be areas of concern. Based on the study conducted in Licking County, Ohio, quality of soil used for wastewater treatment has a positive impact on the price of the property, and its contribution is $\$ 15,752$ as measured in this model. This amount is more than the cost of installing a mound system, therefore, property owners may be inclined to switch to an advanced treatment system with the right information. Federal- and stateassisted programs could be used to provide relief for homeowners who wish to install drip irrigation systems in areas that are not suited for mound systems. Better wastewater treatment improves ground and surface water, which in turn, could lead to more additional benefits such as improved health in the household and increased recreation in the area. Additional research needs to be conducted to capture the full economic value of septic systems. It is hoped that a better understanding of the impacts of untreated wastewater would lead to better private and public policy decisions.

\section{References}

[1] Boone, C.G., Obstacles to infrastructure provision: The struggle to build comprehensive sewer works in Baltimore. Historical Geography, 31, pp. 151-168, 2003. 
[2] Ohio Administrative Code, Chapter 3701-29. Household Sewage Disposal Systems, 1977.

[3] U.S. Census Bureau, American Housing Surveys for the United States, 2007.

[4] USEPA, Septic (Onsite) Systems. United States Environmental Protection Agency, 2010.

[5] Mancl, K.M. \& Slater, B., Suitability assessment of Ohio's soils for soilbased wastewater treatment. Ohio Journal of Science, 101(3/4), pp. 48-58, 2001 Reprinted in Ohio Journal of Environmental Health 52(1):29-37, 2002.

[6] Converse, J.C., Design and Construction of Wisconsin Mounds. Technical report, Small Scale Waste Management Project, Madison, Wisc., 1978.

[7] Ohio Department of Health, Report to the Household Sewage and Small Flow On-site Sewage Treatment System Study Commission, 2008.

[8] Mancl, K.M., A survey of small sewage treatment facilities in Ohio. Ohio Journal of Science, 90(4), pp. 112-117, 1990.

[9] Ohio Environmental Protection Agency, State of the Environment Report. Ohio Comparative Risk Project, 1995. pp 71-86.

[10] Northeast Ohio Areawide Coordinating Agency, Survey of Northeast Ohio Home Sewage Disposal Systems and Semi-Public Sewage Disposal Systems. Technical report, Cleveland, Ohio, 2001.

[11] Maumee River Remedial Action Plan, Maumee River Area of Concern Stream \& Septic Monitoring Study Final Report. Technical report, Perrysburg, Ohio, 2004.

[12] DeWalle, F.B., Failure analysis of large septic tank systems. Journal of the Environmental Engineering Division, 107(1), pp. 229-240, 1981.

[13] Mancl, K.M. \& Slater, B., Why Do Septic Systems Malfunction. Ohio State University Extension Fact Sheet 741, 2000.

[14] Minnesota Pollution Control Agency, Effects of Septic Systems on Ground Water Quality - Baxter, Minnesota. Technical report, St. Paul, Minn., 1999.

[15] USEPA, Giardia: Drinking Water Fact Sheet. United States Environmental Protection Agency, 2000.

[16] Arnade, L.J., Seasonal correlation of well contamination and septic tank distance. Ground Water, 37(6), pp. 920-923, 1999.

[17] DeBorde, D.C., Woessner, W.W., Lauerman, B. \& Ball, P.N., Virus occurrence and transport in a school septic system and unconfirmed aquifer. Ground Water, 36(5), pp. 825-834, 1998.

[18] Yates, M.V., Septic tank density and ground-water contamination. Ground Water, 23(5), pp. 586-591, 1985.

[19] Borchardt, M.A., Chyou, P.H., DeVries, E.O. \& Belongia, E.A., Septic system density and infectious diarrhea in a defined population of children. Environmental Health Perspectives, 111(5), pp. 742-748, 2003.

[20] Fong, T.T., Mansfield, L.S., Wilson, D.L., Schwab, D.J., Molloy, S.L. \& Rose, J.B., Massive microbiological groundwater contamination associated with a waterborne outbreak in Lake Erie, South Bass Island, Ohio. Environmental Health Perspectives, 115(6), pp. 856-864, 2007.

[21] Mancl, K.M. \& Slater, B., Suitability of Ohio Soils for Treating Wastewater. 
Ohio State University Extension Bulletin 896, 2002.

[22] Cangelosi, A., Weiher, R., Taverna, J. \& Cicero, P., Revealing the Economic Value of Protecting the Great Lakes. Northeast-Midwest Institute and National Oceanic and Atmospheric Administration: Washington, D.C.

[23] Hitzhusen, F.J., Economic Valuation of River Systems. Edward Elgar Publishing Ltd.: Cheltenham, U.K.

[24] Hitzhusen, F.J., Ayalasomayajula, R. \& Lowder, S., Economic valuation of a river corridor: Integration of natural resource and development economics. Annual Meeting of the Agricultural Economics Association, Agricultural Economics Association, 1999.

[25] Hitzhusen, F.J., Lowder, S. \& Ayalasomayajula, R., Muskingum River Economic Valuation. Technical report, Rivers Unlimited, Cincinnati, Ohio, 2000 . 